\title{
Fire resistance of the Mt. Epomeo Green Tuff, a widely-used building stone on Ischia Island (Italy)
}

\author{
Michael J. Heap ${ }^{\star \alpha}$, Alexandra R. L. Kushnir ${ }^{\alpha}$, Luke Griffiths $^{\alpha}$, Fabian B. Wadsworth $^{\dagger} \beta$, \\ Gian Marco Marmoni $\gamma$, Matteo Fiorucci $\gamma$, Salvatore Martino $\gamma$, \\ Patrick Baud ${ }^{\alpha}$, H. Albert Gilg ${ }^{\delta}$, Thierry Reuschlé ${ }^{\alpha}$ \\ ${ }^{\alpha}$ Géophysique Expérimentale, Institut de Physique de Globe de Strasbourg (UMR 7516 CNRS, Université de Strasbourg/EOST), \\ 5 rue René Descartes, 67084 Strasbourg cedex, France. \\ $\beta$ Earth E Environmental Sciences, Ludwig Maximilians Universität, Theresienstr. 41/III, 80333 Munich, Germany.

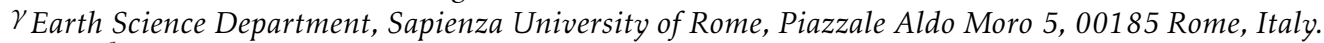 \\ ${ }^{\delta}$ Lehrstuhl für Ingenieurgeologie, Technische Universität München, Munich, Germany.
}

\begin{abstract}
The use of Mt. Epomeo Green Tuff (MEGT) as a building stone is widespread on Ischia Island (Italy). We assess here the fire resistance of MEGT by thermally stressing samples to temperatures up to $1000{ }^{\circ} \mathrm{C}$. Porosity and uniaxial compressive strength increase and decrease from $44 \%$ and $4.5 \mathrm{MPa}$ at ambient temperature to $48 \%$ and 1.5 $\mathrm{MPa}$ following exposure to $1000^{\circ} \mathrm{C}$, respectively. Complementary thermogravimetric and X-ray powder diffraction analyses, experiments that monitor acoustic emissions during heating/cooling, and microstructural observations highlight that these changes are the result of thermal microcracks, formed due to the breakdown of zeolites and clays (MEGT contains $35 \mathrm{wt} . \%$ analcime, $15 \mathrm{wt} . \%$ smectite, and $3 \mathrm{wt} . \%$ illite) at high temperature. Although the stability of structures built from MEGT will be jeopardised at high temperature, a very low thermal diffusivity requires that fires must burn for many hours to compromise the strength of a typical dimension stone: tuffs are tough in the event of fire.
\end{abstract}

\section{RÉSUMÉ}

Le tuf vert de Mt. Epomeo (MEGT) est très utilisé comme matériau de construction dans l'ile d'Ischia (Italie). Nous avons analysé la résistance au feu du MEGT en soumettant cette roche à des traitements thermiques à des températures allant jusqu'à $1000^{\circ} \mathrm{C}$. Si la porosité du MEGT augmente de $44 \%$ à température ambiante, à $48 \%$ à $1000^{\circ} \mathrm{C}$, sa résistance en compression uniaxiale décroit de 4,5 à 1,5 MPa sur le même intervalle de température. Des analyses thermogravimétriques et par diffractométrie de rayons $\mathrm{X}$, l'enregistrement des émissions acoustiques durant le chauffage et le refroidissement, ainsi que des observations de la microstructure montrent que les changements observés sur le MEGT après traitement thermique sont liés au développement de microfissures. Ces microfissures se forment à cause de la rupture des zéolites et des argiles à haute température. Le MEGT contient 35\% d'analcime, $15 \%$ de smectite et $3 \%$ d'illite. Bien que la stabilité de structures construites avec le MEGT puisse être compromise à haute température, la très faible diffusivité thermique de cette roche nécessite un incendie très long (plusieurs heures) pour vraiment réduire la résistance des blocs de roche typiquement utilisés dans les édifices de l'ile d'Ischia. Le tuf peut de ce fait être considéré comme une roche résistante en cas d'incendie.

Keywords: Zeolite; Porosity; Uniaxial compressive strength; Acoustic emissions; Microcracks; X-ray powder diffraction

\section{InTRODUCTION}

Tuffs-deposits from explosive eruptions-have been used worldwide as a building stone for millennia [Heiken 2006]. The use of tuff as a building stone is particularly prevalent in Italy. Notable examples in-

\footnotetext{
*Corresponding author: heap@unistra.fr

${ }^{\dagger}$ now at: Department of Earth Sciences, Durham University, Science Labs, Durham DH1 3LE, UK
}

clude the cities of Naples [e.g. Calcaterra et al. 2000; de'Gennaro et al. 2000; Evangelista et al. 2000; Colella et al. 2001; Calcaterra et al. 2005; Heap et al. 2012; Benedetto et al. 2015; Heap et al. 2018] and Rome [e.g. De Casa et al. 1994; Jackson et al. 2005]. The use of green-coloured tuff from Mt. Epomeo as a building stone is widespread on Ischia Island (a volcanic island in the Tyrrhenian Sea at the northern end of the Gulf of Naples, Italy). The Mt. Epomeo Green Tuff 
(MEGT), a massive green-coloured alkali-trachytic pyroclastic flow deposit, was formed following an explosive caldera-forming eruption about $55 \mathrm{ka}$ [Orsi et al. 1991; Tibaldi and Vezzoli 1998; Brown et al. 2007]. The MEGT represents the largest known eruption on Ischia Island and has an estimated volume of $40 \mathrm{~km}^{3}$ [Tomlinson et al. 2014]. MEGT is commonly used to construct walls and houses (Figure 1), including the striking San Ciro church (Figure 1A). Statues are found hewn from blocks of the green tuff (Figure 1B) and many houses and restaurants are built on top of, or inside, large blocks that litter the slopes of Mt. Epomeo and Mt. Nuovo as a result of historic rock avalanches [Seta et al. 2012; Della Seta et al. 2015] (Figure 1C-D).

Due to the widespread use of tuff as a building stone worldwide, many studies are devoted to understanding, for example, their resistance to fire [e.g. Duvarc1 et al. 2007; Gomez-Heras et al. 2006; Heap et al. 2012], resistance to salt weathering [e.g. Török et al. 2004; Zedef et al. 2007; Vacchiano et al. 2008; Oguchi and Yuasa 2010; Yavuz 2012; Russa et al. 2017], resistance to freeze-thaw weathering [e.g. Chen et al. 2004; Török et al. 2004; Oguchi and Yuasa 2010; Nijland et al. 2010; Ruedrich et al. 2011; Yavuz 2012], and their strength in the presence of water and following wetting-drying cycles [e.g. Jackson et al. 2005; Siedel 2010; Oguchi and Yuasa 2010; Zhu et al. 2011; Benedetto et al. 2015; Heap et al. 2018].

The vulnerability of tuffs often used in construction in the Neapolitan area of Italy to the high temperatures of fire was the focus of a recent study by Heap et al. [2012]. These authors found that the strength of only one of the three tuffs was reduced following exposure to high temperature (up to $1000^{\circ} \mathrm{C}$ ). The weakening of this tuff-the Neapolitan Yellow Tuff-was found to be the result of microcracking and the disintegration of the matrix due to the dehydration and breakdown of zeolites (phillipsite, chabazite, and analcime) at high temperature; the other two tuffs did not contain any zeolites and were therefore unaffected by exposure to high temperature [Heap et al. 2012]. Since the MEGT contains zeolites (Pola et al. [2012] and Marmoni et al. [2017a]), we may expect similar reductions in strength. However, Marmoni et al. [2017a] found that the strength of MEGT did not change systematically following exposure to temperatures up to $300^{\circ} \mathrm{C}$. The influence of higher temperatures, such as those experienced during fires, on the physical properties of MEGT is currently unknown.

Fires are a secondary hazard in tectonically and volcanically active areas, and a Mediterranean climate consisting of hot and dry summers can exacerbate natural and accidental fires. For example, a fire of vast proportions (covering an area of $\sim 1 \mathrm{~km}^{2}$ ) engulfed the wooded southwestern slope of Mt. Epomeo (MEGT forms a significant component of Mt. Epomeo: Marmoni et al. [2017a]), between the towns of Forio and Serrara Fontana, in August 2017 (Figure 2). We present a study designed to better understand the influence of the high temperatures (up to $1000{ }^{\circ} \mathrm{C}$ ) of fire (or from inundation by lava flows) on the physical properties (porosity and strength) of MEGT. Uniaxial compressive strength tests on thermally stressed samples of MEGT are supported by X-ray powder diffraction analyses (XRPD) on "as collected" (i.e. material that has undergone no heating or deformation) and thermally stressed MEGT, thermal property data (thermal diffusivity, thermal conductivity, and specific heat capacity), thermogravimetric data, acoustic emission (AE)a proxy for microcracking-monitoring during heating and cooling, and microstructural observations of thermally stressed samples. Finally, we modelled heat conduction in an MEGT dimension stone to assess timedependent physical property modifications during fire.

\section{EXPERIMENTAL MATERIALS AND METHODS}

The microstructure and mineral content of our block of MEGT was first investigated using scanning electron microscopy (SEM) and X-ray powder diffraction (XRPD), respectively. The block-collected from the northern slope of Mt. Epomeo-is the same block used in recent mechanical studies focussed on gravitational slope deformation [Marmoni et al. 2017a; Marmoni et al. 2017b]. Thin sections were prepared from the as collected material and imaged using a Tescan Vega 2 XMU scanning electron microscope (SEM). The mineral content was quantified using XRPD using a powdered sample of the as collected MEGT. 10 wt.\% $\mathrm{ZnO}$ (internal standard) was added to the MEGT powder and the powdered mixture was ground for $8 \mathrm{~min}$ with $10 \mathrm{ml}$ of isopropyl alcohol in a McCrone Micronising Mill using agate cylinder elements. The XRPD analyses were performed on powder mounts using a PW 1800 X-ray diffractometer $(\mathrm{CuK} \alpha$, graphite monochromator, $10 \mathrm{~mm}$ automatic divergence slit, step-scan $0.02^{\circ} 2 \theta$ increments per second, counting time one second per increment, $30 \mathrm{~mA}, 40 \mathrm{kV}$ ). The phases in the whole rock powders were quantified using the Rietveld program BGMN [Bergmann et al. 1998]. To identify the clay minerals, we also separated $<2 \mu \mathrm{m}$ fractions by gravitational settling and prepared oriented mounts that were X-rayed in an air-dried and an ethylene-glycolated state.

The studied block of MEGT is a heterogeneous greencoloured ignimbrite deposit that contains lithic fragments $(<10 \mathrm{~mm}$ in diameter), porous lapilli (i.e. pumice) fragments $(<20 \mathrm{~mm}$ in diameter $)$, and phenocrysts hosted within an altered matrix (Figure 3; Table 1). The phenocrysts are mainly Na-rich sanidine (17 wt.\%), Na-poor K-feldspar (25 wt.\%), plagioclase (50 wt.\%), and biotite (2 wt.\%) (Figure 3; Table 1). The altered matrix comprises analcime (35 wt.\%), smectite (12 wt.\%), and Fe-rich illite (3 wt.\%) (Table 1). Our block of MEGT is therefore similar in mineral con- 

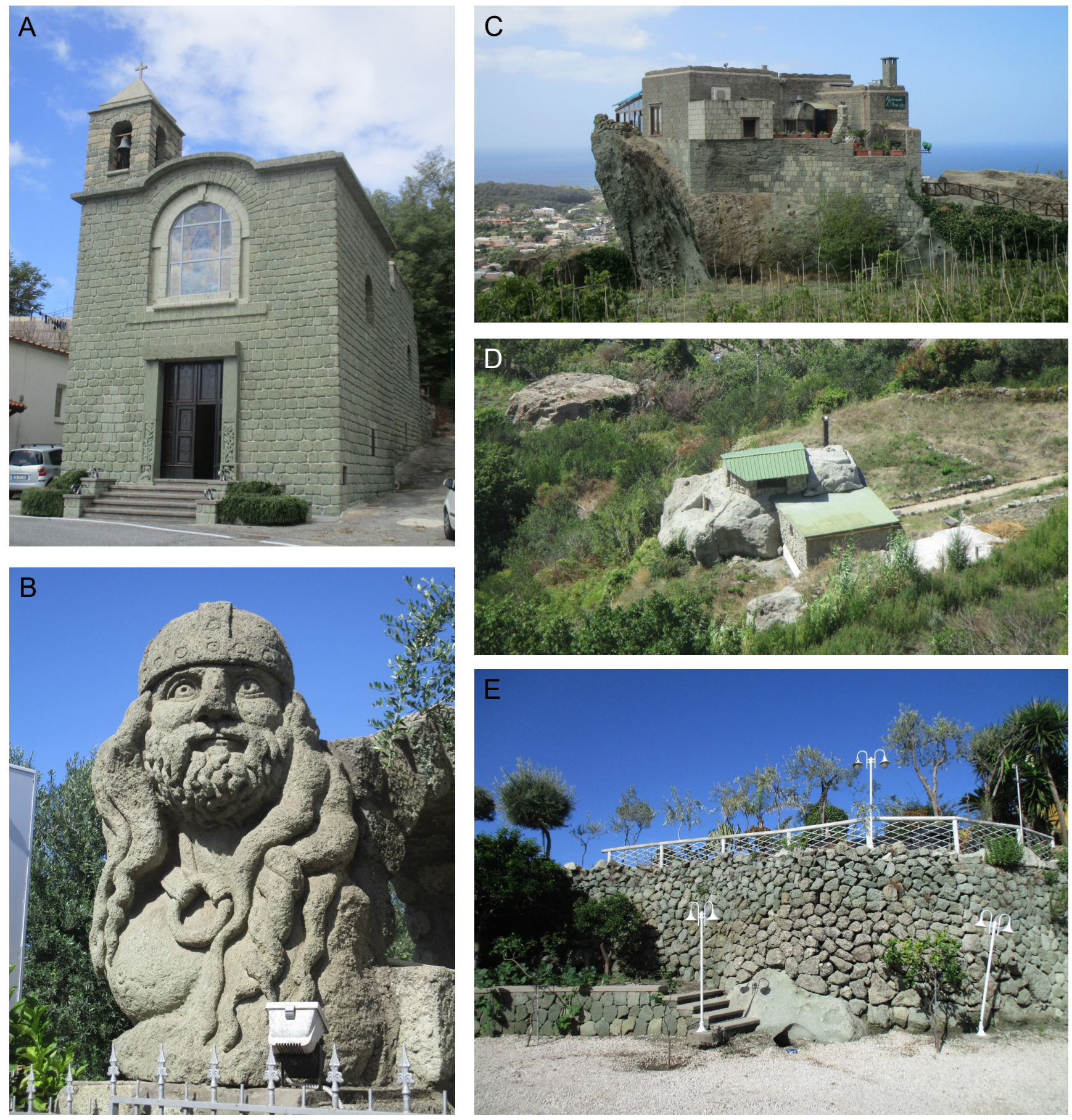

Figure 1: The use of Mt. Epomeo Green Tuff (MEGT) in construction on Ischia Island (Italy). [A] The San Ciro church. [B] Statue carved from a block of MEGT. [C] Restaurant built using MEGT on top of a block of MEGT. [D] House built inside a block of MEGT. [E] Wall constructed using blocks of MEGT. Photo credit for all pictures: M.J. Heap. 

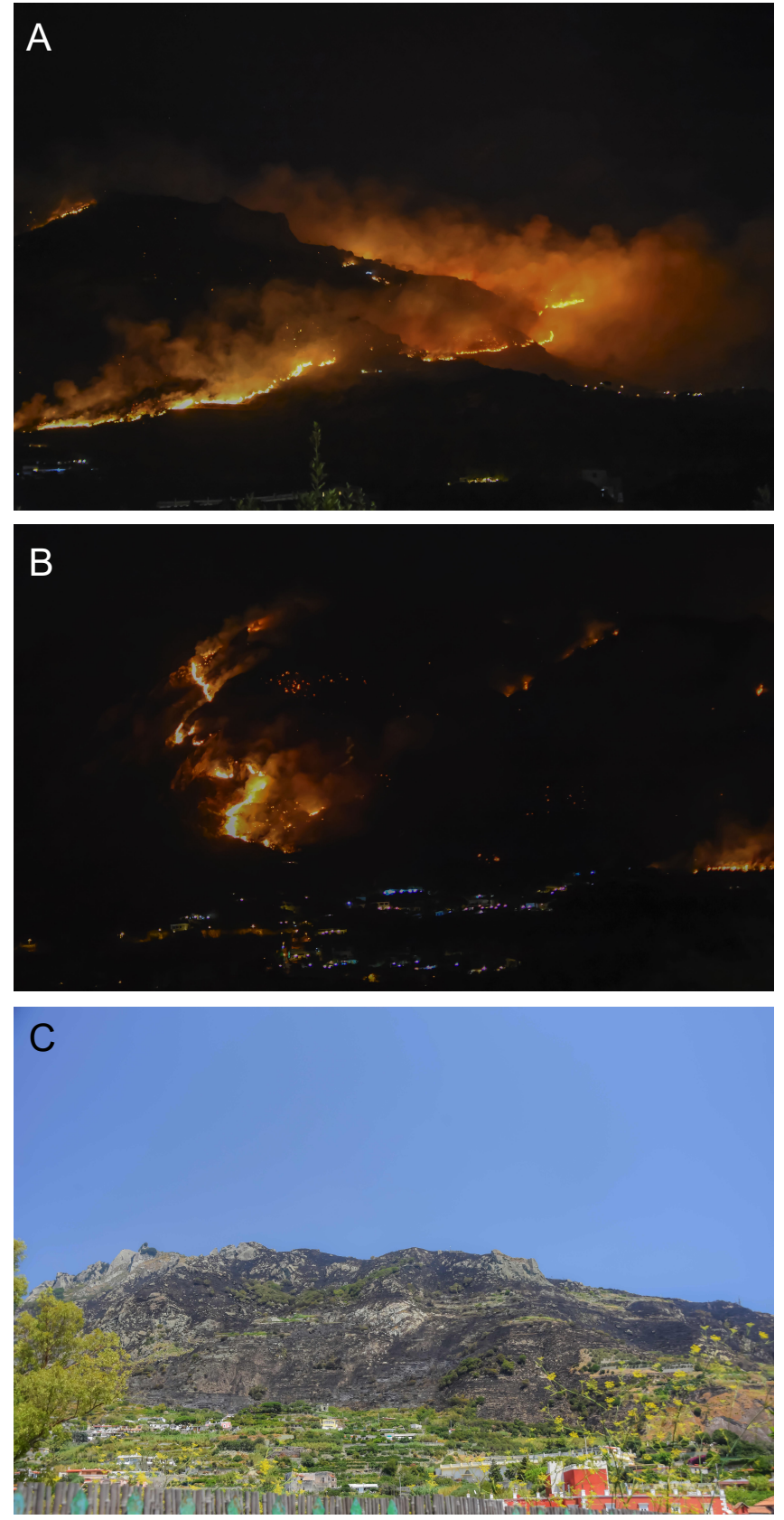

Figure 2: $[\mathrm{A}]$ and $[\mathrm{B}]$ Photographs of the August 2017 fire that engulfed the wooded southwestern slopes of Mt. Epomeo. [C] Photograph of the charred volcanic slope following the fire. Photographs taken by, and used with permission from, Michele Abbagnara.

tent to the clasts (pebble- to boulder-sized) of MEGT found in polymictic breccia that covers large portions of the area from just downslope of the summit of Mt. Epomeo to the southern coast several km away [Altaner et al. 2013]. This mineral content indicates a high alteration temperature $\left(>70{ }^{\circ} \mathrm{C}\right)$ in a mostly closed chemical system [Altaner et al. 2013]. Our XRPD analysis also found subordinate calcite (1 wt.\%) and cristobalite (<1 wt.\%) (Table 1) and our microstructural analysis highlighted the presence of iron and titanium oxides
Table 1 - Quantitative bulk mineralogical composition, determined using X-ray powder diffraction (XRPD), for the "as collected" (i.e. material that has undergone no heating or deformation) Mt. Epomeo Green Tuff (MEGT) used in this study.

\begin{tabular}{rc}
\hline Mineral & Mineral content (wt.\%) \\
\hline Na-rich sanidine & $17 \pm 2$ \\
Plagioclase & $5 \pm 1$ \\
Biotite & $2 \pm 1$ \\
Analcime & $35 \pm 2$ \\
Na-poor K-feldspar & $25 \pm 2$ \\
Cristobalite & $<1$ \\
Calcite & $1 \pm 2$ \\
Smectite & $12 \pm 3$ \\
Fe-rich illite & $3 \pm 2$ \\
\hline
\end{tabular}

(Figure 3). Our XPRD analysis found no residual glass (Table 1). Microstructurally, the MEGT is very heterogeneous and contains pores of various sizes (from a few tens of microns up to a few millimetres in diameter) (Figure 3) and large (often several millimetres long) altered porous fragments (Figure 3).

Cylindrical samples were cored in the same orientation from a single block of MEGT to a diameter of $25 \mathrm{~mm}$ and cut and precision-ground to a nominal length of $60 \mathrm{~mm}$. Samples were cored so as to avoid centimetric-scale juvenile lapilli and lithic fragments. To avoid the washout of porous lapilli and the fine fraction, the sample block was first soaked in water and then cored dry (i.e. samples were cored without running water). A total of 25 cylindrical samples were prepared, gently washed to remove any water-soluble grinding fluid, and then dried in a vacuum at $40^{\circ} \mathrm{C}$ for at least $48 \mathrm{~h}$. Their connected porosities were determined using a helium pycnometer (Micromeritics AccuPyc II 1340). The average connected porosity of these 25 samples was measured to be $44.7 \%$ (standard deviation of $1.6 \%$ ). To avoid problems with sample variability, we selected a subset of 14 cores with similar connected porosities (average of $44.8 \%$ and a standard deviation of $0.7 \%$ ). Pairs of samples were heated to target temperatures of $100,200,300,500,750$, and $1000^{\circ} \mathrm{C}$ in an oven at ambient pressure. Samples were heated at a constant heating rate of $1^{\circ} \mathrm{Cmin}^{-1}$, left at the target temperature for $2 \mathrm{~h}$, before being cooled back to ambient temperature at $1{ }^{\circ} \mathrm{Cmin}^{-1}$. The colour of the samples changed from pale green to yellow-orange following exposure to $500{ }^{\circ} \mathrm{C}$ and, finally, to bloodorange following exposure to $1000{ }^{\circ} \mathrm{C}$ (Figure 4). The connected porosities of the thermally stressed samples were then remeasured using the helium pycnometer. A pair of samples was left unheated to serve as a comparison. Finally, the 14 samples were deformed uniaxially at ambient temperature at a strain rate of $1.0 \times$ 

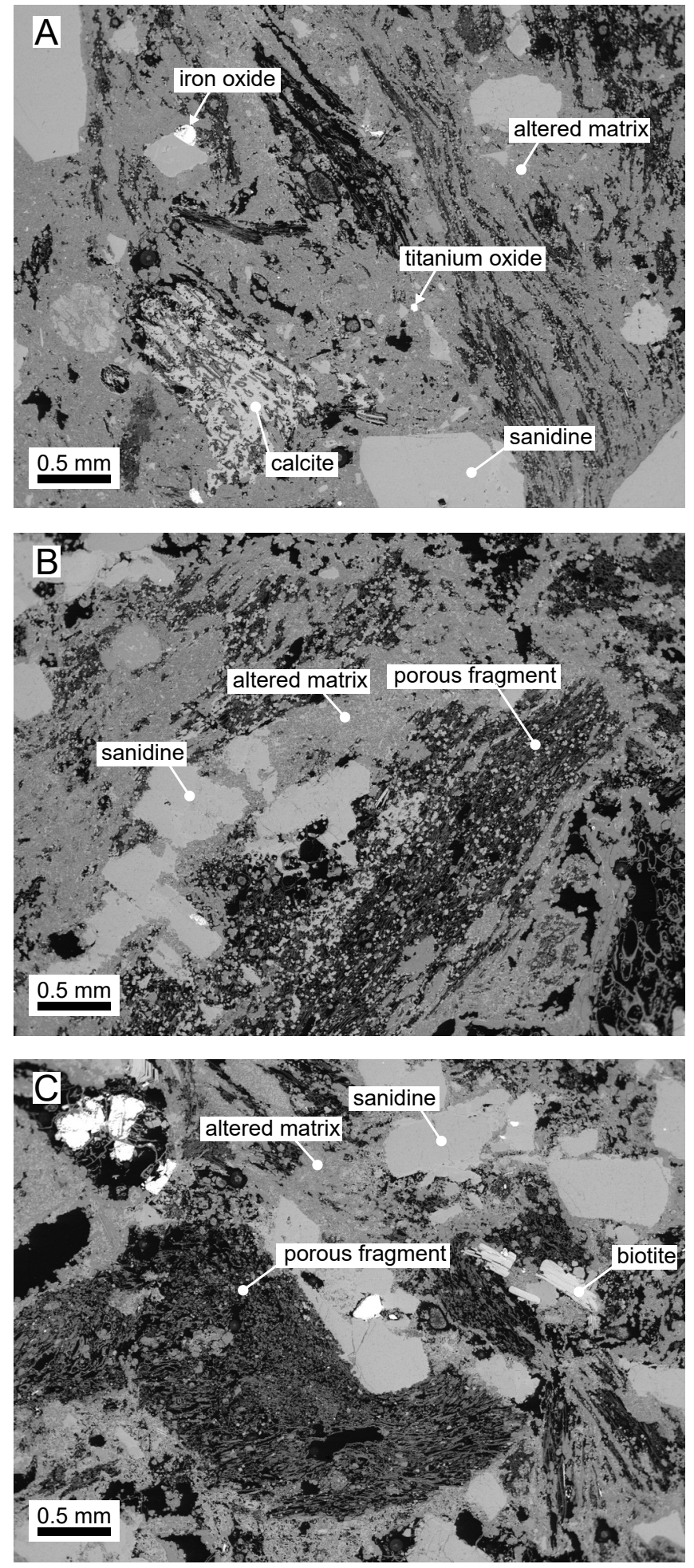

Figure 3: Backscattered scanning electron microscope images of "as collected" (i.e. material that has undergone no heating or deformation) Mt. Epomeo Green Tuff (MEGT).

$10^{-5} \mathrm{~s}^{-1}$ until macroscopic failure. A lubricating wax was applied to the ends of the samples to reduce frictional constraint at the interface between the sample and the pistons [Labuz and Bridell 1993]. The output of AE during deformation was monitored using a wideband (bandwidth of 100-1000 kHz; from Physical Acoustics) AE sensor-embedded within the bottom endcap-connected to a USB AE node (a single channel AE digital signal processor with a built-in $26 \mathrm{~dB}$ preamplifier; from Physical Acoustics). AEs are high frequency elastic wave packets generated by the rapid release of strain energy and are frequently used as a proxy for microcracking in laboratory experiments [e.g. Lockner 1993]. In our experiments, an AE "hit" was counted if the amplitude of the received signal exceeded the detection threshold (set at $30 \mathrm{~dB}$ ). The AE energy (in arbitrary units) of an AE hit was calculated as the area under the received waveform.

We also performed thermo-gravimetric analysis (TGA) on a powdered sample $(\sim 40 \mathrm{mg})$ of MEGT using a Netzsch Pegasus 404 thermal analysis device. The powdered sample was heated in an atmosphere flushed with argon at a flow rate of $20 \mathrm{ml} \mathrm{min}^{-1}$ inside a platinum crucible (with lid). The powders were first heated to $100{ }^{\circ} \mathrm{C}$. This temperature was kept constant for 20 minutes to ensure that any free water (i.e. not structurally bound) was removed. The powder was then heated at $1{ }^{\circ} \mathrm{Cmin}^{-1}$ to $1000{ }^{\circ} \mathrm{C}$. This type of analysis tracks the mass loss of a sample as a result of, for example, the dehydroxylation of zeolites during heating (see, for example, de'Gennaro and Colella [1989] and Heap et al. [2012]).

The output AE during heating and cooling was recorded on an additional cylindrical sample $(20 \mathrm{~mm}$ in diameter and nominally $40 \mathrm{~mm}$ in length) using a system specifically designed to record AE at high temperature. The setup consists of a servo-controlled uniaxial press and a tube furnace [Griffiths et al. 2018]. The sample was held between the pistons of the uniaxial press, under a constant servo-controlled load of 100 $\mathrm{N}$. The tube furnace was placed around the sample and pistons and programmed to heat the sample at a rate of $1{ }^{\circ} \mathrm{C} \mathrm{min}^{-1}$ to a target temperature of $700{ }^{\circ} \mathrm{C}$, dwell for $2 \mathrm{~h}$ at the target temperature, before cooling the sample back to ambient temperature at a rate of $1^{\circ} \mathrm{C} \mathrm{min}-1$. AE activity was detected using a micro80 AE sensor (bandwidth of $200-900 \mathrm{kHz}$ and a resonant frequency of 325 $\mathrm{kHz}$; from Physical Acoustics) embedded in the centre of the upper piston, which acts as a continuous wave guide. The AE sensor was connected to a USB AE node, and the detection threshold was set at $40 \mathrm{~dB}$. This system is optimised for recording AE during heating: (1) the upper piston acts as a continuous wave guide, circumventing attenuation due to surface interfaces; (2) the sensor is embedded within the centre of the piston rather than on the side, improving amplitude and frequency content of the signal; (3) the piston is cooled (to protect the sensor) using a custom-built air-cooling system that does not generate detectable electrical or mechanical noise; (4) the servo-controlled displacement of the lower piston during heating and cooling compensates for their thermal expansion and contraction, providing a constant load on the sample to avoid any oscil- 


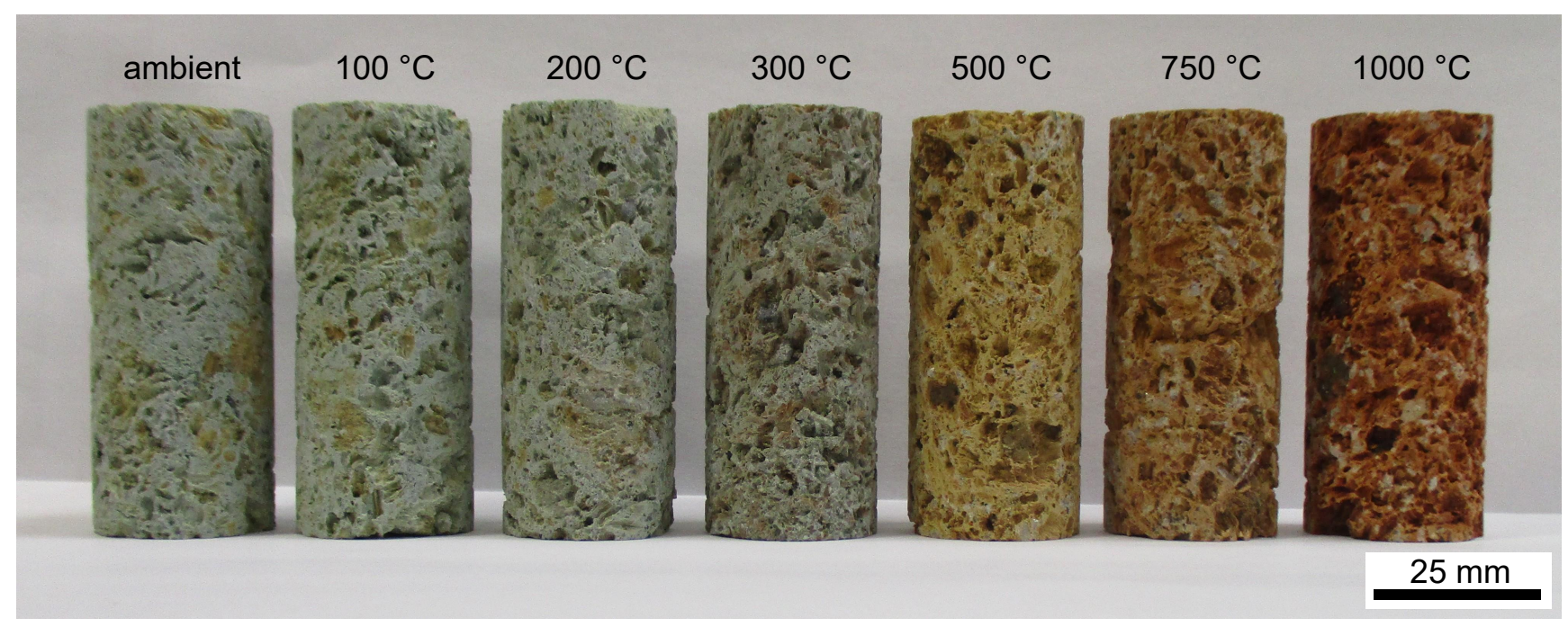

Figure 4: Photograph of a suite of thermally stressed samples of Mt. Epomeo Green Tuff (MEGT). Temperature quoted above each sample is the thermal stressing temperature. "Ambient" (i.e. ambient temperature) indicates a sample that underwent no thermal stressing.

lation in coupling and, ultimately, in the AE detection threshold [Griffiths et al. 2018].

The thermal diffusivity, thermal conductivity, and specific heat capacity of the MEGT were measured using a Hot Disk TPS 500 Thermal Constants Analyser using the Hot Disk method [Gustafsson 1991; Gustavsson et al. 1994]. A Kapton sensor $6.403 \mathrm{~mm}$ in radius was sandwiched between two $40 \mathrm{~mm}$-diameter cylindrical samples (20 mm long) and measurements were conducted at a system output power of $150 \mathrm{~mW}$ for $40 \mathrm{~s}$. The measurements were conducted at ambient temperature $\left(21^{\circ} \mathrm{C}\right)$. Specific heat capacity was calculated by the system after measurement. A series of four consecutive measurements was performed on different sample surfaces to account for sample heterogeneity. Individual measurements were performed at least $5 \mathrm{~min}$ apart, to ensure that the sample temperature returned to $21^{\circ} \mathrm{C}$ before the subsequent measurement. No corrections were made to the measured value of thermal conductivity [see Nabelek et al. 2010, for example].

Microstructural analyses were performed on thin sections prepared from samples of MEGT thermally stressed to 500 and $750{ }^{\circ} \mathrm{C}$ using the aforementioned SEM.

\section{Results}

3.1 Connected porosity and uniaxial compressive strength

The stress-strain curves of selected experiments at each thermal stressing temperature are shown in Figure 5, and are typical of those for brittle rock in compression [e.g. Hoek and Bieniawski 1965; Brace et al. 1966; Scholz 1968]. Figure 5 shows that the strength of MEGT is clearly reduced as thermal stressing temperature increases, best shown on a plot of uniaxial compressive strength (UCS) as a function of thermal stressing temperature (Figure 6A). We also find that connected porosity increases with thermal stressing temperature (Figure 6B). In detail, connected porosity and UCS increase and decrease from $44 \%$ and $4.5 \mathrm{MPa}$ at ambient temperature to $48 \%$ and $1.5 \mathrm{MPa}$ following exposure to $1000^{\circ} \mathrm{C}$, respectively (Figure 6; Table 2). The stress-strain curves and cumulative AE energy curves are plotted for a sample left at ambient temperature and for samples thermally stressed to temperatures of 500 and $1000^{\circ} \mathrm{C}$ in Figure 7 . While the output of AE accelerates up to failure in the ambient and $500^{\circ} \mathrm{C}$ sample (Figure 7A and 7B), typical for brittle rock in compression [e.g. Scholz 1968], AE activity for the sample thermally stressed to $1000^{\circ} \mathrm{C}$ does not accelerate up to failure. These data also show that the cumulative AE energy during deformation and failure is much greater for the $1000^{\circ} \mathrm{C}$ sample than for the ambient and $500{ }^{\circ} \mathrm{C}$ samples (Figure 7).

\subsection{Thermogravimetric analysis}

Relative mass as a function of temperature is shown in Figure 8. The data show that MEGT loses $\sim 3.2 \%$ of its mass up to a temperature of $\sim 300^{\circ} \mathrm{C}$, and a further $\sim 1.1 \%$ from $\sim 300$ to $\sim 630^{\circ} \mathrm{C}$ (Figure 8). There is little change in mass from $\sim 630^{\circ} \mathrm{C}$ up to the maximum temperature of $1000^{\circ} \mathrm{C}$ (Figure 8).

\subsection{Acoustic emission activity during heating and cooling}

The output of AE during heating to and cooling from $700{ }^{\circ} \mathrm{C}$ are shown in Figure 9. Significant AE activity 
Table 2 - Summary of the experimental data collected for this study.

\begin{tabular}{cccc}
\hline $\begin{array}{c}\text { Sample } \\
\text { number }\end{array}$ & $\begin{array}{c}\text { Thermal stressing } \\
\text { temperature }\left({ }^{\circ} \mathrm{C}\right)\end{array}$ & $\begin{array}{c}\text { Connected } \\
\text { porosity }(\%)\end{array}$ & $\begin{array}{c}\text { Uniaxial } \\
\text { compressive } \\
\text { strength (MPa) }\end{array}$ \\
\hline MEGT 1 & - & 43.5 & 4.94 \\
MEGT 3 & - & 44.4 & 4.05 \\
MEGT 6 & 100 & 44.9 & 3.98 \\
MEGT 8 & 100 & 44.1 & 5.18 \\
MEGT 7 & 200 & 46.1 & 2.60 \\
MEGT 9 & 200 & 44.6 & 4.91 \\
MEGT 10 & 300 & 47.3 & 2.57 \\
MEGT 12 & 300 & 47.1 & 3.65 \\
MEGT 13 & 500 & 47.2 & 2.74 \\
MEGT 14 & 500 & 46.1 & 4.19 \\
MEGT 15 & 750 & 49.3 & 2.69 \\
MEGT 16 & 750 & 48.6 & 1.94 \\
MEGT 17 & 1000 & 47.9 & 1.72 \\
MEGT 18 & 1000 & 48.1 & 1.32 \\
\hline
\end{tabular}

MEGT $=$ Mt. Epomeo Green Tuff.

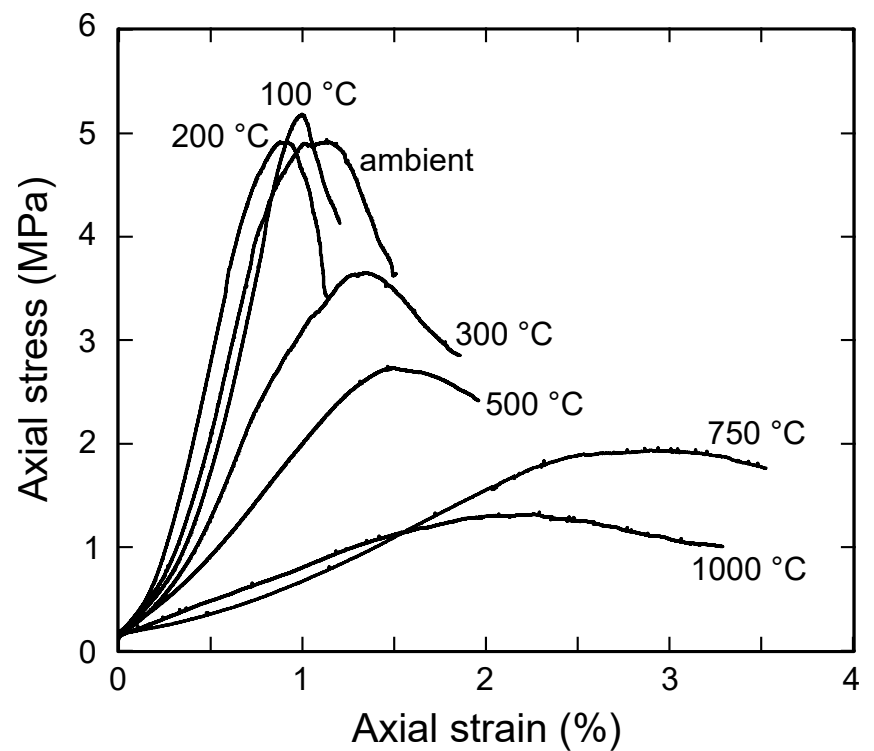

Figure 5: Uniaxial stress-strain curves for samples of Mt. Epomeo Green Tuff (MEGT). Temperature next to each curve corresponds to the thermal stressing temperature. "Ambient" (i.e. ambient temperature) indicates a sample that underwent no thermal stressing.

starts at $\sim 200^{\circ} \mathrm{C}$ during the heating cycle and continues up to the maximum temperature of $700^{\circ} \mathrm{C}$ (Figure $9 \mathrm{~B})$. There are two large spikes in $\mathrm{AE}$ activity during heating, at a temperature of $\sim 370-380^{\circ} \mathrm{C}$ and a temperature of $\sim 540-580^{\circ} \mathrm{C}$ (Figure $9 \mathrm{~A}$ ). Far fewer AE were recorded during the cooling phase than during the heating phase (Figure 9B).

\subsection{Thermal property data}

Values of thermal conductivity, thermal diffusivity, and volume-specific heat capacity for MEGT are $0.499 \mathrm{WmK}^{-1}, 0.451 \mathrm{~mm}^{2} \mathrm{~s}^{-1}$, and $1.132 \mathrm{MJ} \mathrm{m}^{-3} \mathrm{~K}^{-1}$, respectively (Table 3 ).

\subsection{Microstructural observations}

Backscattered SEM images of samples of MEGT exposed to temperatures of 500 and $700^{\circ} \mathrm{C}$ (i.e. before and after the large spike in $\mathrm{AE}$ activity at temperatures of $\sim 540-675^{\circ} \mathrm{C}$; Figure 9) are shown in Figure 10. Microcracks are observed within the altered matrix of these thermally stressed samples (Figure 10B). Many more microcracks are seen in the $750{ }^{\circ} \mathrm{C}$ sample (Figure $10 \mathrm{C}$ and $10 \mathrm{D}$ ) than in the sample heated to $500^{\circ} \mathrm{C}$ (Figure 10A and 10B). The formed microcracks appear very tortuous and often deflect around the small crystals that form the altered matrix (Figure 10B). The large microcrack seen in the sample heated to $750{ }^{\circ} \mathrm{C}$ appears to have originated from inside one of the porous fragments Figure 10C and 10D).

3.6 Mineral content of MEGT following exposure to high temperature

To better understand the changes to the mineral content of the MEGT following exposure to high temperature, we performed XRPD analysis on a sample of powdered MEGT that had been thermally stressed to $1000^{\circ} \mathrm{C}$. The XRPD procedure was performed as de- 
Table 3 - Thermal properties of Mt.Epomeo Green Tuff, Neapolitan Yellow Tuff, Grey Campanian Ignimbrite, and high-strength concrete.

\begin{tabular}{cccc}
\hline Sample & $\begin{array}{c}\text { Thermal } \\
\text { conductivity } \\
\left(\mathrm{W} \mathrm{mK}^{-1}\right)\end{array}$ & $\begin{array}{c}\text { Thermal } \\
\text { diffusivity } \\
\left(\mathrm{mm}^{2} \mathrm{~s}^{-1}\right)\end{array}$ & $\begin{array}{c}\text { Volume-specific } \\
\text { heat capacity } \\
\left(\mathrm{MJ} \mathrm{m}^{-3} \mathrm{~K}^{-1}\right)\end{array}$ \\
\hline Mt.Epomeo Green Tuff & 0.4990 & 0.4513 & 1.1324 \\
$\begin{array}{c}\text { Neapolitan Yellow Tuff } \\
\text { Grey Campanian Ignimbrite }\end{array}$ & 0.4004 & 0.2902 & 1.3801 \\
High-strength concrete & 0.4148 & 0.4360 & 0.9246 \\
\hline
\end{tabular}
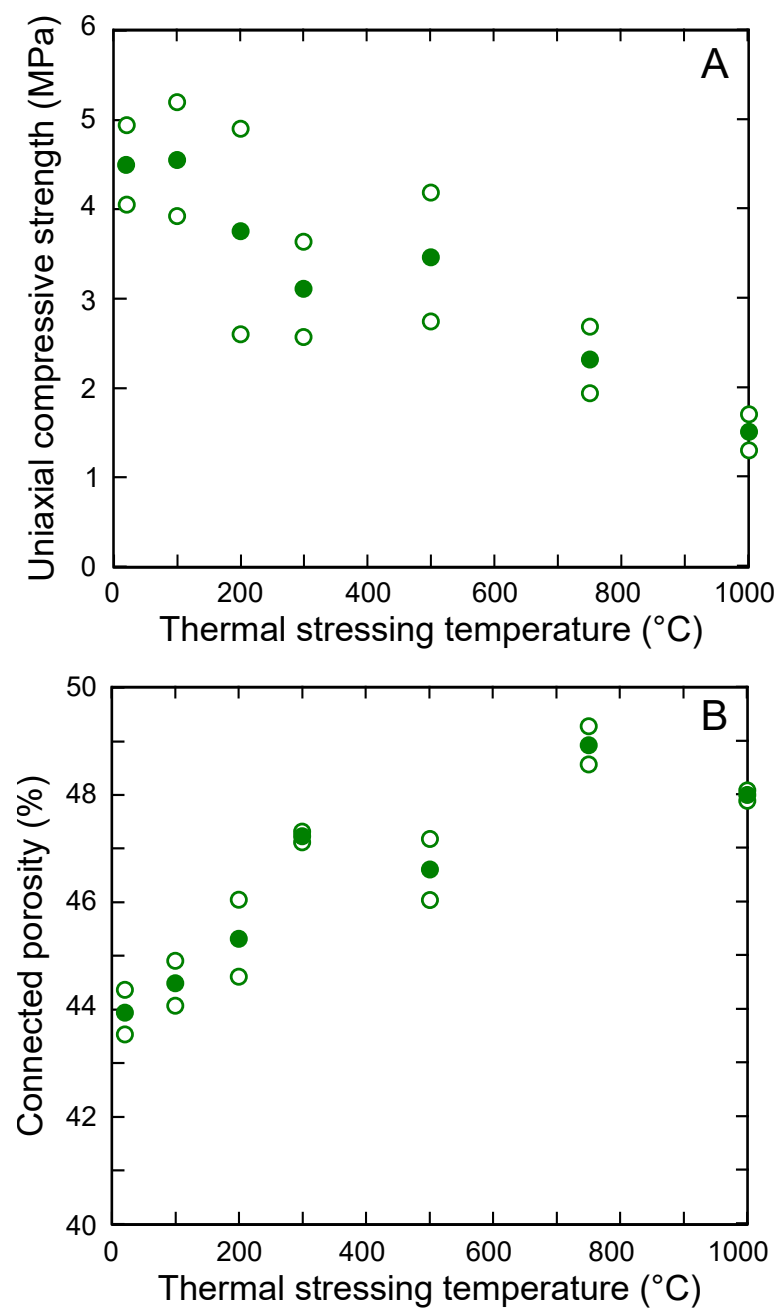

Figure 6: $[\mathrm{A}]$ Uniaxial compressive strength (UCS) as a function of thermal stressing temperature for Mt. Epomeo Green Tuff (MEGT) (open symbols). The filled symbols are the averages of two measurements (Table 2). [B] Connected porosity as a function of thermal stressing temperature for MEGT (open symbols). The filled symbols are the averages of two measurements (Table 2). scribed above. The XRPD profiles for an as collected sample and a sample exposed to $1000^{\circ} \mathrm{C}$ are shown in Figure 11. The curves show that, following exposure to $1000^{\circ} \mathrm{C}$, the sample has lost analcime, smectite, and Fe-rich illite (Figure 11). The curves also indicate a slight decrease in biotite and the growth of an amorphous phase and other hitherto unidentified phases (Figure 11).

\section{Discussion}

4.1 The weakening of MEGT following exposure to high temperature

Our data show that the strength of MEGT is reduced from $\sim 4.5 \mathrm{MPa}$ at ambient temperature down to $\sim 1.5$ MPa following exposure to $1000^{\circ} \mathrm{C}$ (Figure 6A; Table 2), a reduction in strength of $\sim 70 \%$. A similar reduction in strength was seen for Neapolitan Yellow Tuff following exposure to high temperature: strength was reduced from $\sim 3.4 \mathrm{MPa}$ at ambient temperature to $\sim 0.7 \mathrm{MPa}$ following exposure to $750^{\circ} \mathrm{C}$, a reduction of $\sim 80 \%$ (Figure 12; Heap et al. [2012]). The weakening of the Neapolitan Yellow Tuff following exposure to high temperature was found to be the result of microcracking due to the dehydration and breakdown of zeolites (phillipsite, chabazite, and analcime) [Heap et al. 2012].

Our thermogravimetric analysis can be interpreted here to record the dehydration and dehydroxylation of the zeolites and clays within the matrix (Figure 8). Indeed, our XRPD analyses (Figure 11) show that MEGT loses analcime, smectite, and illite following exposure to high temperature. Our thermogravimetric analysis can provide the temperature ranges at which these reactions take place, to guide our mechanical and microstructural interpretations. Smectite typically dehydrates at temperatures $\sim 100-150^{\circ} \mathrm{C}$ and undergoes mass loss due to dehydroxylation at temperatures $\sim 400-600^{\circ} \mathrm{C}$ [Girgis et al. 1987]. However, the smectite within our block of MEGT is probably characterised by a cis-vacant dioctahedral structure due to the abundance of $\mathrm{Al}$ and therefore likely dehydroxylates at slightly higher temperatures, between 650 and 

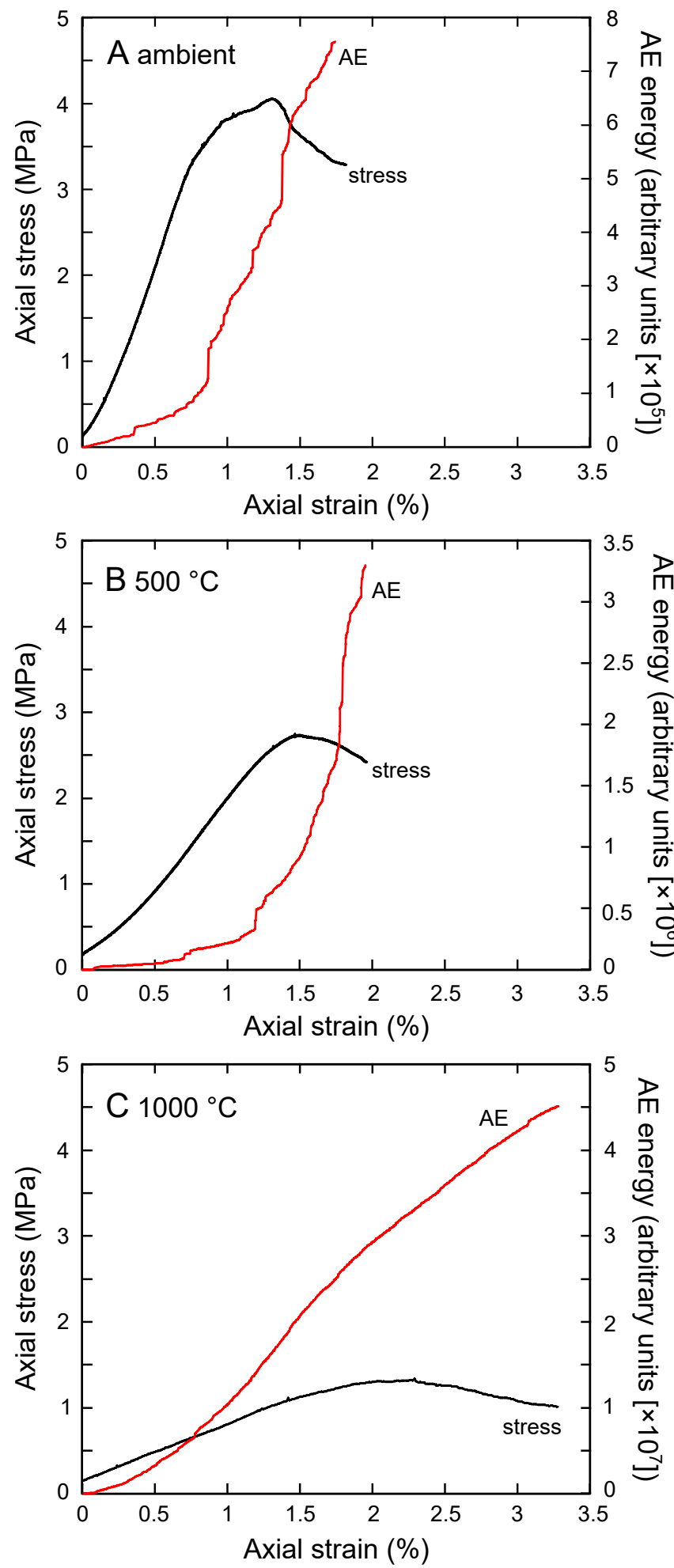

Figure 7: Uniaxial stress-strain curves for samples of Mt. Epomeo Green Tuff (MEGT) together with the cumulative output of AE energy. [A] MEGT sample left at ambient temperature (i.e. a sample that underwent no thermal stressing). [B] MEGT sample thermally stressed to $500^{\circ} \mathrm{C}$. [C] MEGT sample thermally stressed to $1000^{\circ} \mathrm{C}$.

$700{ }^{\circ} \mathrm{C}$ [Wolters and Emmerich 2007]. The dehydra-

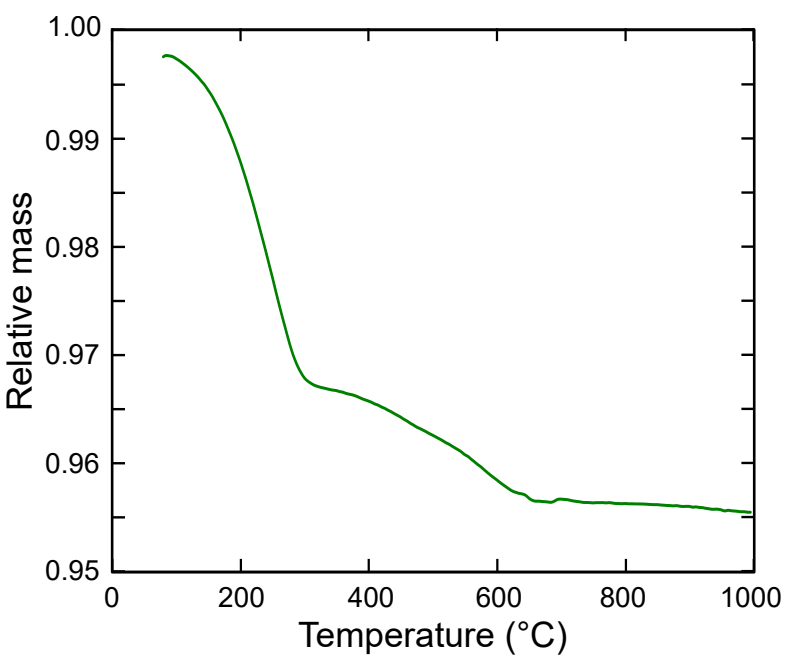

Figure 8: Relative mass as a function of temperature for Mt. Epomeo Green Tuff (MEGT).

tion of Fe-illite occurs at a temperature of $\sim 100^{\circ} \mathrm{C}$ and large mass losses due to dehydroxylation occur at temperatures from $\sim 350^{\circ} \mathrm{C}$ [Murad 1996]. Mass losses due to the dehydroxylation of Fe-illite peak at $\sim 565^{\circ} \mathrm{C}$ and Mössbauer spectroscopy highlighted the disappearance of $\mathrm{Fe}_{2}^{+}$at temperatures of $\sim 250^{\circ} \mathrm{C}$ [Murad 1996]. Analcime irreversibly loses water and phillipsite undergoes a partial reversible dehydration at $\sim 240^{\circ} \mathrm{C}$ [de'Gennaro and Colella 1989]. The structure of analcime reaches a maximum distortion at $\sim 375^{\circ} \mathrm{C}$, associated with the complete loss of water and a reduction in volume [Cruciani and Gualtieri 1999]. Our thermogravimetric analysis shows that the majority of the mass loss occurs up to a temperature of $\sim 300^{\circ} \mathrm{C}$ (Figure 8), a likely result of the high proportion of analcime (35 wt.\%) compared to smectite and Fe-rich illite (12 and $3 \mathrm{wt} . \%$, respectively). The mass loss between $\sim 400$ and $\sim 650{ }^{\circ} \mathrm{C}$ is likely associated with the dehydroxylation Fe-rich illite [Murad 1996] and perhaps the start of the dehydroxylation of the Al-rich smectite [Wolters and Emmerich 2007]. The thermogravimetric data for MEGT (Figure 8) are similar to data for other zeolite-bearing tuffs [e.g. de'Gennaro and Colella 1989; Heap et al. 2012].

Our AE data show that MEGT undergoes thermal microcracking during heating and cooling (Figure 9). The output of AE has been previously used to monitor thermal microcracking in rock during heating [e.g. Glover et al. 1995] and during heating and cooling [e.g. Heap et al. 2014a; Browning et al. 2016; Griffiths et al. 2018]. Thermal microcracks are thought to be the consequence of stresses that arise due to the mismatch in thermal expansion and contraction of the mineral constituents. We observed two large spikes in AE activity at temperatures of $\sim 370-380^{\circ} \mathrm{C}$ and $\sim 540-580^{\circ} \mathrm{C}$ (Figure 9). The temperature of the first $\mathrm{AE}$ spike corresponds to the temperature of the maximum volume reduction in analcime $\left(\sim 375^{\circ} \mathrm{C}\right.$; Cruciani and Gualtieri [1999]). We suggest that the breakdown of analcime-which likely 

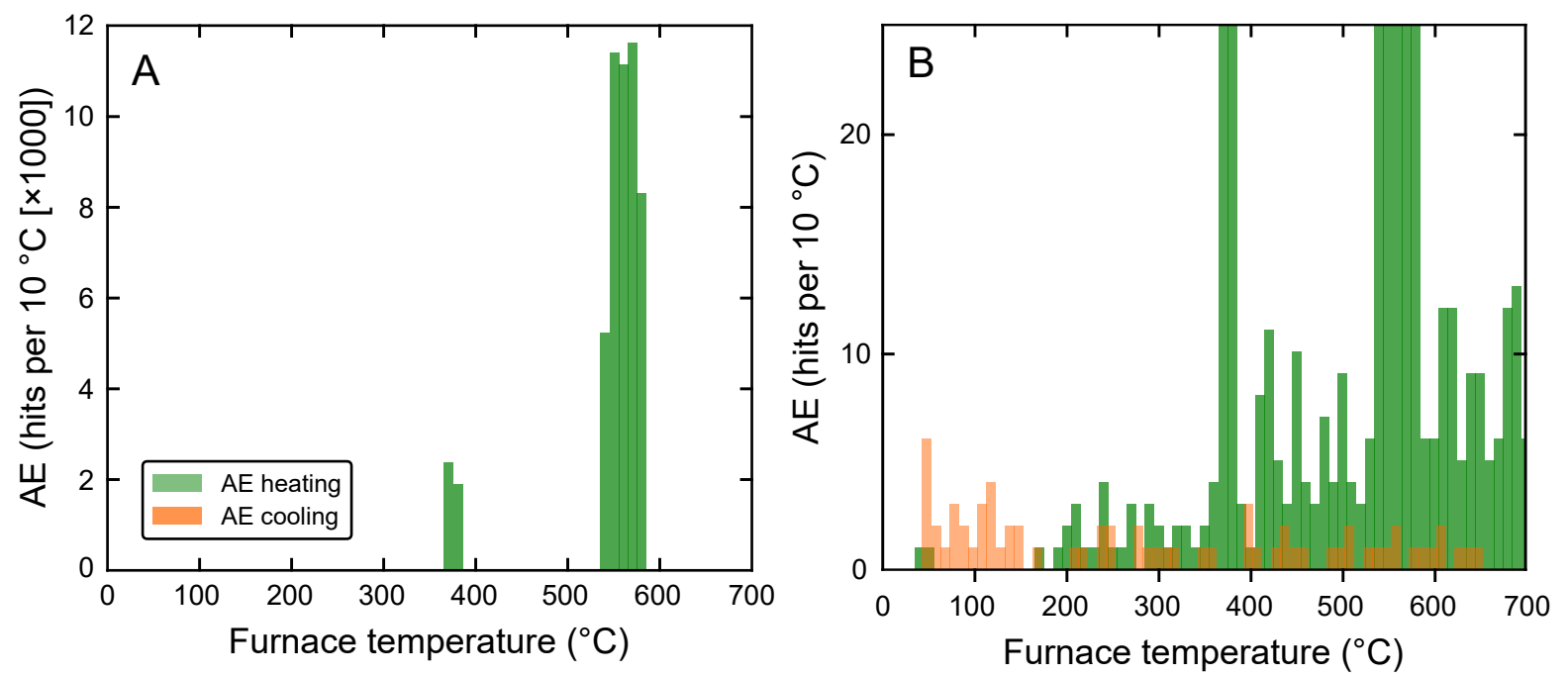

Figure 9: $[\mathrm{A}]$ The number of acoustic emission $(\mathrm{AE})$ hits per $10^{\circ} \mathrm{C}$ recorded during a thermal stressing experiment on Mt. Epomeo Green Tuff (MEGT) to a maximum temperature of $700^{\circ} \mathrm{C}$. [B] A graph showing a zoom of the data shown in panel $[\mathrm{A}]$ to highlight the $\mathrm{AE}$ hits recorded during cooling.
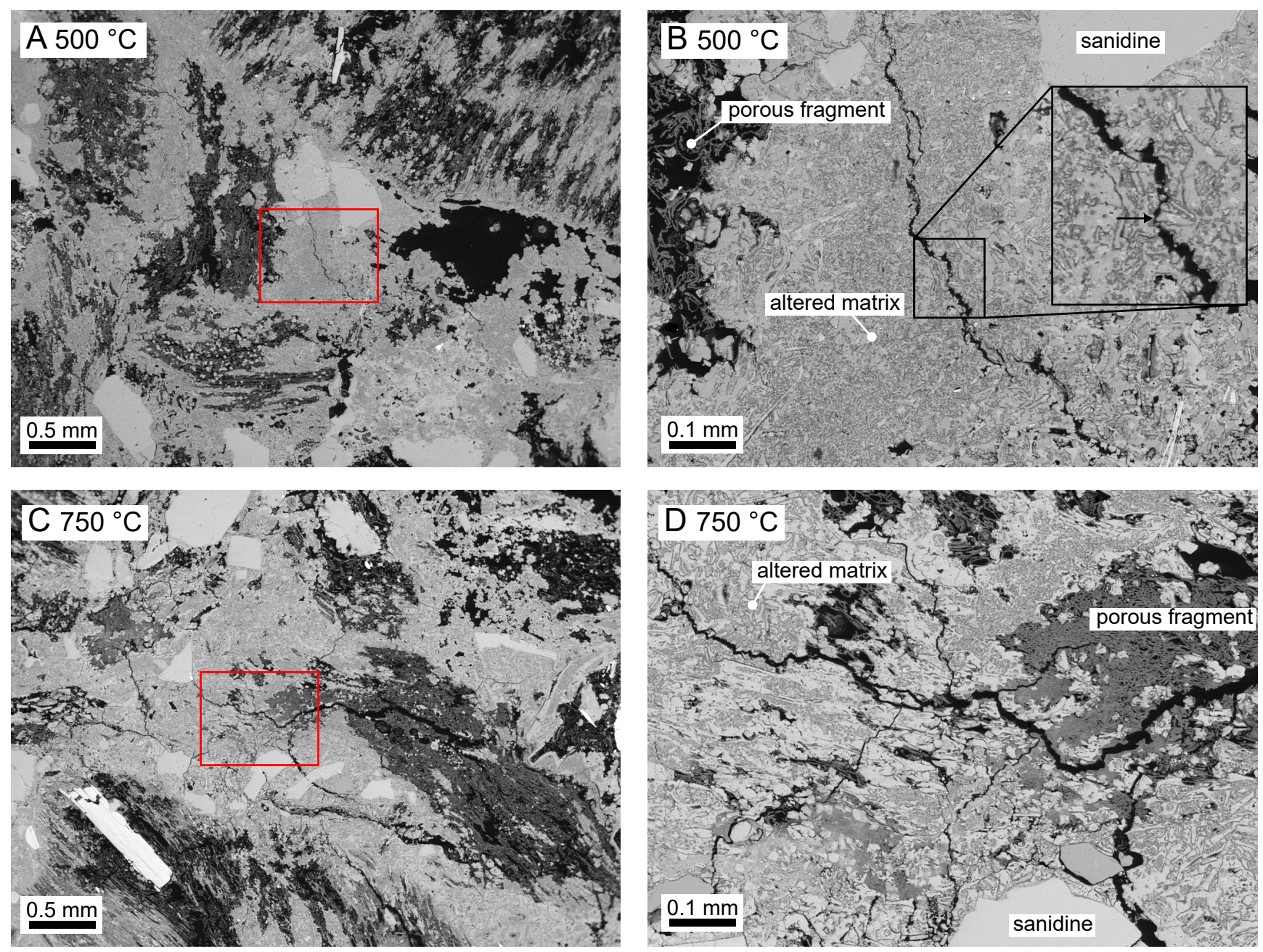

Figure 10: Backscattered scanning electron microscope images of Mt. Epomeo Green Tuff (MEGT) that have been thermally stressed to $500^{\circ} \mathrm{C}$ (panel [A]) and $750^{\circ} \mathrm{C}$ (panel [D]). Panels [B] and [D] show zoomed-in images from panels $[A]$ and $[B]$, respectively (indicated by the red rectangles). Inset in panel $[B]$ shows a close-up of the fracture; the arrow indicates a crystal fragment that has deflected the path of the tortuous fracture. 


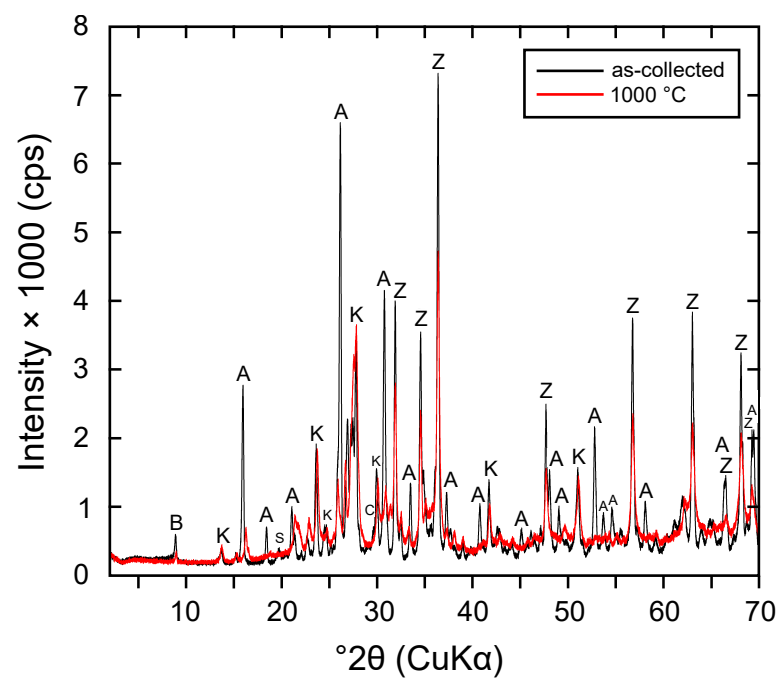

Figure 11: X-ray powder diffraction (XRPD) profile for a sample of "as collected" (i.e. material that has undergone no heating or deformation) Mt. Epomeo Green Tuff (MEGT) and a sample of MEGT exposed to $1000{ }^{\circ} \mathrm{C}$. $\mathrm{Z}$ - ZnO; B - biotite; A - analcime; $\mathrm{S}$ - smectite; $\mathrm{C}$ - calcite; $\mathrm{K}$ - K-feldspar.

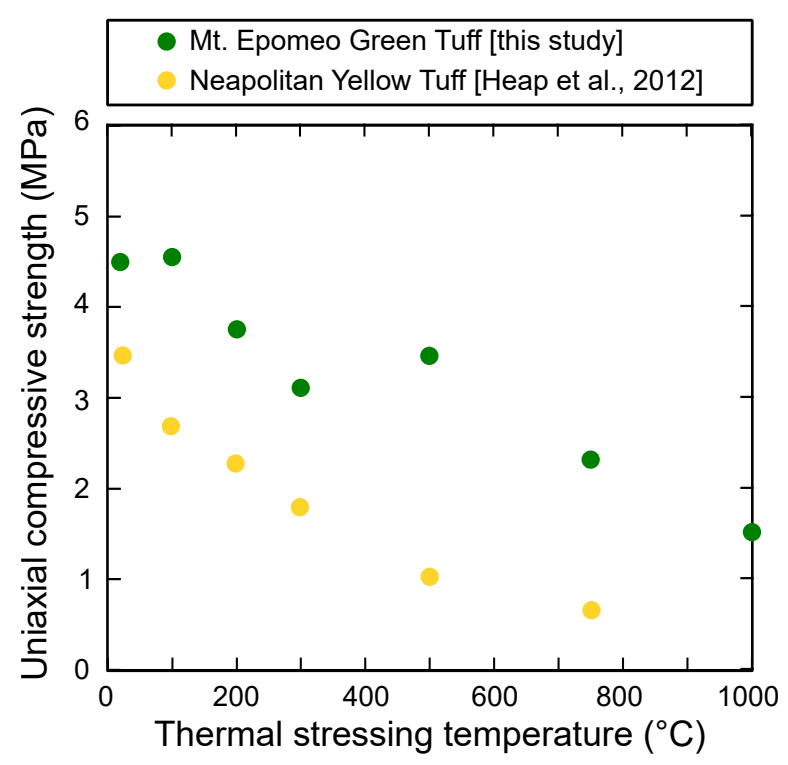

Figure 12: Uniaxial compressive strength (UCS) as a function of thermal stressing temperature for Mt. Epomeo Green Tuff (MEGT) (data from this study; symbols represent the average of two experiments, see Table 2) and Neapolitan Yellow Tuff (data from Heap et al. [2012]). contributed to the lithification of ignimbrite deposits [e.g. de'Gennaro et al. 2000]—resulted in microcracking, as exhibited by our AE data (Figure 9) and observed in our microstructural analysis (Figure 10B). We attribute the second spike in AE activity ( $\sim 540$ $580^{\circ} \mathrm{C}$; Figure 9) primarily to the dehydroxylation of Fe-rich illite, for which the maximum mass loss occurs at a temperature of $\sim 565^{\circ} \mathrm{C}$ [Murad 1996]. We note that this temperature is slightly below that required for the dehydroxylation of Al-rich smectite (between 650 and $700^{\circ} \mathrm{C}$ ) [Wolters and Emmerich 2007], although we cannot definitively rule out that some of the smectite within the MEGT dehydroxylated within this lower temperature range. The large number of AE hits detected within this temperature range $(\sim 540-$ $580^{\circ} \mathrm{C}$; Figure 9) are reflected in the microstructure: we observe many, tortuous microcracks in the sample thermally stressed to $750{ }^{\circ} \mathrm{C}$ (Figure 10C and 10D).

We therefore conclude that the observed weakening in MEGT following exposure to high temperature (Figures 5 and 6) is primarily due to the dehydration and breakdown of analcime up to a temperature of $\sim 400^{\circ} \mathrm{C}$ and the dehydroxylation of Fe-rich illite and smectite at temperatures between $\sim 350$ and $\sim 700^{\circ} \mathrm{C}$ - both of which contribute to thermal microcracking (Figures 8 , 9 and 10$)$.

4.2 Heat conduction modelling: how tough is tuff in the event of fire?

To assess fire resistance of buildings constructed using MEGT, we consider the diffusion of heat through a halfspace of MEGT. The diffusion of heat through a Cartesian half-space can be determined by solving:

$$
\frac{d T(z)}{d t}=\frac{1}{\alpha} \frac{\partial^{2} T}{\partial z^{2}}
$$

where $T$ is temperature, $z$ is the distance from the heat source, $t$ is time, and $\alpha$ is the thermal diffusivity of the material. Our determination of $\alpha$ was not dependent on temperature, and so we can make a simplification to Equation 1 that results in the error function solution that is analytical:

$$
\frac{T(z)-T_{w}}{T_{i}-T_{w}}=1-\operatorname{erf}\left(\frac{z}{2 \sqrt{\alpha t}}\right)
$$

where the limits of $T_{w}$ and $T_{i}$ represent the temperature of the wall heat source and the initial temperature of block, respectively. In this formulation, $2 \sqrt{\alpha t}$ is the lengthscale of diffusion used to normalize $z$ on the right hand side of Equation 2. Our conceptual model considers a width of MEGT consistent with a typical dimension stone ( $300 \mathrm{~mm}$; see, for example, the stones used in the San Ciro church shown in Figure 1A) and assumes a fire temperature of $T_{w}=1000^{\circ} \mathrm{C}$. We solve Equation 2 for temperature at $0<z<300 \mathrm{~mm}$ and at times: 1 , 
5, 10, and 20 hours. The results of our thermal modelling are presented in Figure 13A. Figure 13A shows a rectangle for each time step, designed to represent the dimension stone $(300 \mathrm{~mm})$. The fire (at a constant temperature of $1000^{\circ} \mathrm{C}$ ) is exposed to the left hand side of the dimension stone and the isotherms (indicated by a colour-coded scale: black - cold; white - hot) migrate into the stone from left to right. When $t=0 \mathrm{~h}$ (i.e. the first rectangle), for example, the dimension stone is entirely black, indicating that the temperature is $20^{\circ} \mathrm{C}$. Figure $13 \mathrm{~A}$ shows that the $750{ }^{\circ} \mathrm{C}$ isotherm (the temperature at which the microstructure is greatly affected (Figure 10C and 10D) and the strength is notably lower (Figures 5 and 6)) reaches $18 \mathrm{~mm}$ into the block after 1 h, $39.5 \mathrm{~mm}$ after $5 \mathrm{~h}, 57.5 \mathrm{~mm}$ after $10 \mathrm{~h}$, and $81 \mathrm{~mm}$ after $20 \mathrm{~h}$ (Figure 13A).

If we compare these model predictions with those for siliceous-aggregate, high-strength concrete (HSC) (the same material used in Heap et al. [2013]; $\alpha=$ $1.4537 \mathrm{~mm}^{2} \mathrm{~s}^{-1}$; Table 2) (Figure 13B), we find, due to its higher thermal diffusivity, that the $750^{\circ} \mathrm{C}$ isotherm (also an important isotherm for the physical degradation of HSC due to the decarbonation of calcium carbonate between 650 and $740{ }^{\circ} \mathrm{C}$; Heap et al. [2013]) requires much shorter timescales to traverse the block (Figure 13B). In the case of the $\mathrm{HSC}$, the $750^{\circ} \mathrm{C}$ isotherm reaches $29 \mathrm{~mm}$ into the block after $1 \mathrm{~h}, 73$ $\mathrm{mm}$ after $5 \mathrm{~h}, 103 \mathrm{~mm}$ after $10 \mathrm{~h}$, and $145.5 \mathrm{~mm}$ after $20 \mathrm{~h}$ (Figure 13B). Thermal property measurements on two other types of tuff commonly used in construction in Italy-the Neapolitan Yellow Tuff and the grey Campanian Ignimbrite (the same materials used in Heap et al. [2012] and Heap et al. [2014b]) — show that similarly porous tuffs also have very low thermal diffusivities (Table 3). These tuffs will therefore show similar heating profiles to the MEGT shown in Figure 13A. Therefore, although the connected porosity and uniaxial compressive strength of MEGT increase and decrease, respectively, with increasing thermal stressing temperature (Figures 5 and 6), our modelling shows that the low thermal diffusivity of MEGT (and other similarly porous tuffs) requires that fires must burn for many hours to jeopardise the stability of a typical dimension stone (Figure 13).

\section{Concluding Remarks}

Due to its widespread use as a building material on Ischia Island (Italy; Figure 1), we examined the fire resistance of Mt. Epomeo Green Tuff (MEGT). Although the connected porosity and uniaxial compressive strength of MEGT increase and decrease, respectively, with increasing thermal stressing temperature (Figure 6) - due to the formation microcracks (Figure 11) as a result of the dehydration and breakdown of analcime and clays (illite and smectite)- the low thermal diffusivity of MEGT requires that fires must burn for many
$A$
MEGT
$0.4513 \mathrm{~mm}^{2} \mathrm{~s}^{-1}$

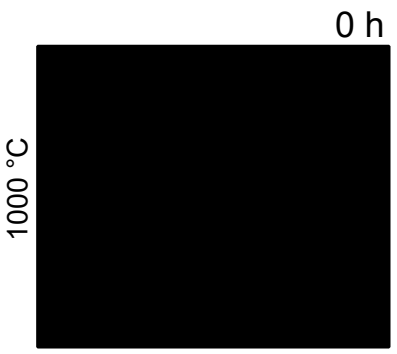

$1 \mathrm{~h}$

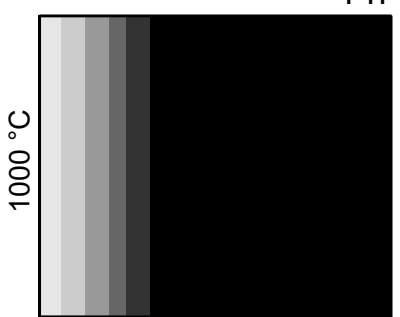

$5 \mathrm{~h}$

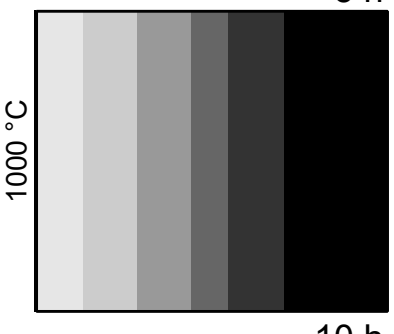

$10 \mathrm{~h}$

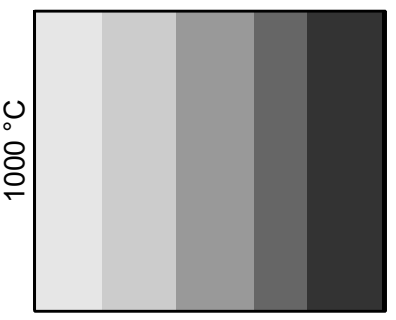

$20 \mathrm{~h}$
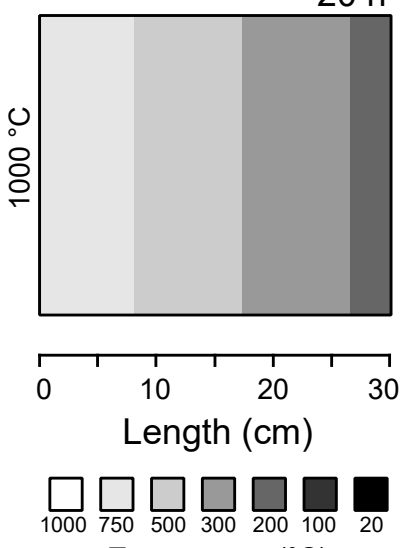

Temperature $\left({ }^{\circ} \mathrm{C}\right)$
B $\quad \mathrm{HSC}$ $1.4537 \mathrm{~mm}^{2} \mathrm{~s}^{-1}$

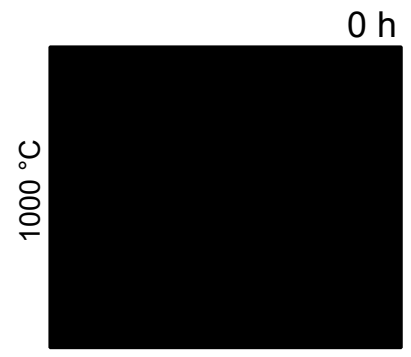

$1 \mathrm{~h}$

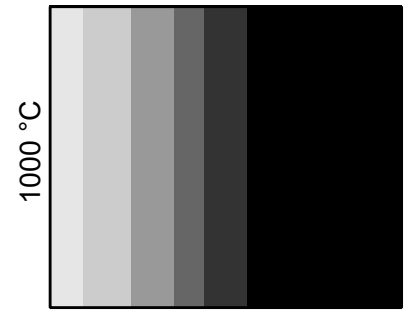

$5 \mathrm{~h}$

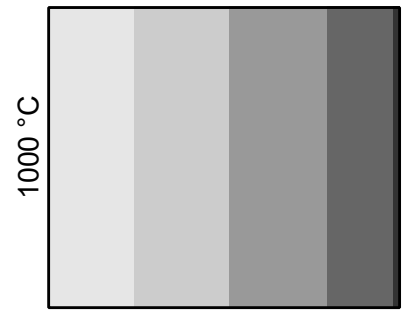

$10 \mathrm{~h}$

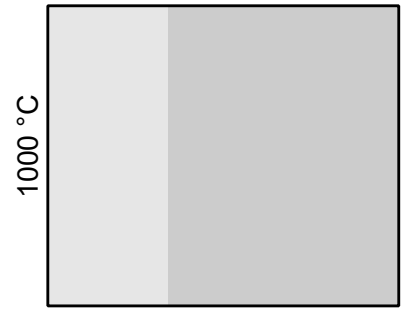

$20 \mathrm{~h}$
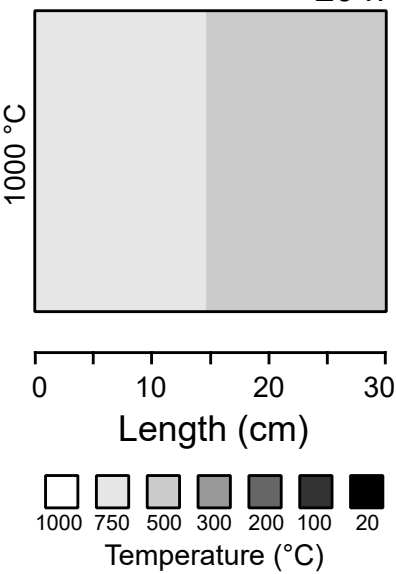

Figure 13: Thermal modelling showing the isotherms within a $300 \mathrm{~mm}$ block (represented by the rectangles) of [A] Mt. Epomeo Green Tuff (MEGT) and [B] highstrength concrete (HSC) for a constant fire temperature of $1000^{\circ} \mathrm{C}$ (from the left) after $0,1,5,10$, and 20 hours. 
hours to jeopardise the stability of a typical dimension stone (Figure 13). We further note that concrete walls are generally thinner than walls constructed using natural dimension stones and, as such, the $750^{\circ} \mathrm{C}$ isotherm would likely travel through a concrete wall on a timescale shorter than that depicted in Figure 13. We conclude therefore that, in spite of the reported weakening, tuffs are tough in the event of fire. We recommend, in areas with a volcanically active past, that natural volcanic materials are used in modern construction due to their fire resistance, sustainability, and aesthetic qualities, rather than relying on concretes that are associated with an additional $\mathrm{CO}_{2}$ fingerprint [e.g. Worrell et al. 2001], a low resistance to fire (compared to the tuffs discussed herein), and a short service life. In the case of Ischia Island we also highlight that, although the temperature of the fumaroles on the volcanic slopes currently rarely exceeds $100^{\circ} \mathrm{C}$, and that the temperatures of the present-day shallow hydrothermal system are estimated to be $\sim 300{ }^{\circ} \mathrm{C}$ [Chiodini et al. 2004], an increase in temperature during renewed volcanic unrest could weaken the MEGT forming the volcanic slopes, increasing the risk of catastrophic slope failure [e.g. Marmoni et al. 2017a].

\section{ACKNOWLedgements}

This work was funded by the "Partenariats Hubert Curien (PHC) GALILEE 2016-2017" grant (project number 37180VC) "Landslide-triggered tsunami hazard in the Mediterranean: improving risk mitigation strategies by understanding natural processes". We wish to thank Bertrand Renaudié, and Olivier Lengliné for laboratory assistance and Gilles Morvan for his assistance on the SEM. We'd like to thank Michele Abbagnara (https://micheleabbagnara.weebly.com) for kindly providing his pictures of the August 2017 fire. The comments of two anonymous reviewers helped to improve this manuscript.

\section{Author Contributions}

M.J. Heap prepared the samples, performed the measurements of porosity and strength, took the photograph of the buildings, performed the microstructural analysis, and wrote the manuscript. A.R.L. Kushnir performed the thermal property measurements, and assisted with the thermal modelling and microstructural analysis. L. Griffiths performed the acoustic emission experiment and analysed the data. F.B. Wadsworth performed the thermogravimetric analysis and the thermal modelling. H.A. Gilg performed the XRPD analysis and analysed the data. G.M. Marmoni, M. Fiorucci, and S. Martino led the field campaign and collected the block of tuff. P. Baud translated the abstract. T. Reuschlé provided instrumental experimental support. All authors had a hand in the interpretation of the data and the writing of the manuscript.

\section{Data AVAilability}

The stress-strain data, thermogravimetric data, and the $\mathrm{AE}$ data during heating and cooling are hosted on figshare: https://figshare.com/s/22dc2d3077893b36e1ca.

\section{COPYRIGHT NOTICE}

(C) The Author(s) 2018. This article is distributed under the terms of the Creative Commons Attribution 4.0 International License, which permits unrestricted use, distribution, and reproduction in any medium, provided you give appropriate credit to the original author(s) and the source, provide a link to the Creative Commons license, and indicate if changes were made.

\section{REFERENCES}

Altaner, S., C. Demosthenous, A. Pozzuoli, and G. Rolandi (2013). "Alteration history of Mount Epomeo Green Tuff and a related polymictic breccia, Ischia Island, Italy: evidence for debris avalanche". Bulletin of Volcanology 75.5. Dor: 10 . 1007/s00445-013-0718-1. Benedetto, C. D., P. Cappelletti, M. Favaro, S. Graziano, A. Langella, D. Calcaterra, and A. Colella (2015). "Porosity as key factor in the durability of two historical building stones: Neapolitan Yellow Tuff and Vicenza Stone". Engineering Geology 193, pp. 310319. Dor: 10.1016/ j .enggeo.2015.05.006.

Bergmann, J., P. Friedel, and R. Kleeberg (1998). "BGMN_a new fundamental parameters based Rietveld program for laboratory X-ray sources, its use in quantitative analysis and structure investigations". CPD Newsletter 20.5.

Brace, W. F., B. W. Paulding, and C. Scholz (1966). "Dilatancy in the fracture of crystalline rocks". Journal of Geophysical Research 71.16, pp. 3939-3953. DoI: 10. 1029/ jz071i016p03939.

Brown, R. J., G. Orsi, and S. de Vita (2007). "New insights into Late Pleistocene explosive volcanic activity and caldera formation on Ischia (southern Italy)". Bulletin of Volcanology 70.5, pp. 583-603. DOI: 10 . 1007 / s00445-007-0155-0.

Browning, J., P. Meredith, and A. Gudmundsson (2016). "Cooling-dominated cracking in thermally stressed volcanic rocks". Geophysical Research Letters 43.16, pp. 8417-8425. Dor: 10.1002/2016gl070532.

Calcaterra, D., P. Cappelletti, A. Langella, V. Morra, A. Colella, and R. de'Gennaro (2000). "The building stones of the ancient centre of Naples (Italy): Piperno from Campi Flegrei. A contribution to the knowledge of a long-time-used stone". Journal of Cultural Heritage 1.4, pp. 415-427. DoI: 10 . 1016 / s 1296 2074 ( 00 ) 01097-9. 
Calcaterra, D., A. Langella, R. de'Gennaro, M. de'Gennaro, and P. Cappelletti (2005). "Piperno from Campi Flegrei: a relevant stone in the historical and monumental heritage of Naples (Italy)". Environmental Geology 47.3, pp. 341-352. Dor: 10. 1007/s00254-004-1156-3.

Chen, T., M. Yeung, and N. Mori (2004). "Effect of water saturation on deterioration of welded tuff due to freeze-thaw action". Cold Regions Science and Technology 38.2-3, pp. 127-136. Dor: $10.1016 / \mathrm{j}$. coldregions.2003.10.001.

Chiodini, G., R. Avino, T. Brombach, S. Caliro, C. Cardellini, S. D. Vita, F. Frondini, D. Granirei, E. Marotta, and G. Ventura (2004). "Fumarolic and diffuse soil degassing west of Mount Epomeo, Ischia, Italy". Journal of Volcanology and Geothermal Research 133.1-4, pp. 291-309. DOI: 10.1016/s0377 0273 ( 03 ) 00403-7.

Colella, C., M. de'Gennaro, and R. Aiello (2001). "Use of Zeolitic Tuff in the Building Industry". Reviews in Mineralogy and Geochemistry 45.1, pp. 551-587. DoI: 10.2138/rmg.2001.45.16.

Cruciani, G. and A. Gualtieri (1999). "Dehydration dynamics of analcime by in situ synchrotron powder diffraction". American Mineralogist 84.1-2, pp. 112119. DoI: $10.2138 / \mathrm{am}-1999-1-212$.

De Casa, G., G. Giglio, G. Lombardi, and M. Mariottini (1994). "Characterization and state of decay of the volcanic tuff of the Tabularium in the Roman Forum, Italy". Lavas and volcanic tuffs: proceedings of the international meeting, Easter Island, Chile, 25-31 October, 1990. International Centre for the Study of the Preservation and the Restoration of Cultural Property, pp. 107-127.

de'Gennaro, M., D. Calcaterra, P. Cappelletti, A. Langella, and V. Morra (2000). "Building stone and related weathering in the architecture of the ancient city of Naples". Journal of Cultural Heritage 1.4, pp. 399-414. DoI: 10 . 1016/s1296-2074 ( 00 ) 01096 7 .

de'Gennaro, M. and C. Colella (1989). "Use of thermal analysis for the evaluation of zeolite content in mixtures of hydrated phases". Thermochimica Acta 154.2, pp. 345-353. Dor: 10 . 1016/0040-6031 ( 89 ) 85472-3.

Della Seta, M., C. Esposito, G. M. Marmoni, S. Martino, A. Paciello, C. Perinelli, and G. Sottili (2015). "Geological constraints for a conceptual evolutionary model of the slope deformations affecting Mt. Nuovo at Ischia (Italy)". Italian Journal of Engineering Geology and Environment 15.2, pp. 15-28.

Duvarcı, Ö. Ç., Y. Akdeniz, F. Özmıhçı, S. Ülkü, D. Balköse, and M. Çiftçioğlu (2007). "Thermal behaviour of a zeolitic tuff". Ceramics International 33.5, pp. 795-801. Dor: 10.1016 / j . ceramint . 2006.01. 003.

Evangelista, A., S. Aversa, T. Pescatore, and F. Pinto (2000). "Soft rocks in southern Italy and role of vol- canic tuffs in the urbanization of Naples". Proceedings of the II International Symposium on 'The Geotechnics of Hard Soils and Soft Rocks', Napoli. Vol. 3, pp. 1243-1267.

Girgis, B., K. El-Barawy, and N. Felix (1987). "Dehydration kinetics of some smectites: a thermogravimetric study". Thermochimica Acta 111, pp. 9-19. Dor: 10 . 1016/0040-6031 (87) 88029-2.

Glover, P. W. J., P. Baud, M. Darot, P. G. Meredith, S. A. Boon, M. LeRavalec, S. Zoussi, and T. Reuschlé (1995). " $\alpha / \beta$ phase transition in quartz monitored using acoustic emissions". Geophysical Journal International 120.3, pp. 775-782. Dor: $10.1111 /$ j . $1365-$ 246x. 1995. tb01852.x.

Gomez-Heras, M., M. Hajpál, M. Álvarez de Buergo, A. Török, R. Fort, and M. Varas (2006). "Evolution of porosity in Hungarian building stones after simulated burning". Heritage Weathering and Conservation HWC-2006. Taylor E Francis, Rotterdam, pp. 513-519.

Griffiths, L., O. Lengliné, M. J. Heap, P. Baud, and J. Schmittbuhl (2018). "Thermal Cracking in Westerly Granite Monitored Using Direct Wave Velocity, Coda Wave Interferometry, and Acoustic Emissions". Journal of Geophysical Research: Solid Earth 123.3, pp. 2246-2261. DoI: 10. 1002/2017 jb015191.

Gustafsson, S. E. (1991). "Transient plane source techniques for thermal conductivity and thermal diffusivity measurements of solid materials". Review of Scientific Instruments 62.3, pp. 797-804. DOI: 10 . 1063/1.1142087.

Gustavsson, M., E. Karawacki, and S. E. Gustafsson (1994). "Thermal conductivity, thermal diffusivity, and specific heat of thin samples from transient measurements with hot disk sensors". Review of Scientific Instruments 65.12, pp. 3856-3859. DoI: 10.1063/1. 1145178.

Heap, M. J., P. Baud, P. G. Meredith, S. Vinciguerra, and T. Reuschlé (2014b). "The permeability and elastic moduli of tuff from Campi Flegrei, Italy: implications for ground deformation modelling". Solid Earth 5.1, pp. 25-44. DoI: 10.5194 / se-5-25-2014.

Heap, M. J., J. I. Farquharson, A. R. L. Kushnir, Y. Lavallée, P. Baud, H. A. Gilg, and T. Reuschlé (2018). "The influence of water on the strength of Neapolitan Yellow Tuff, the most widely-used building stone in Naples (Italy)". Bulletin of Volcanology. DOI: 10 . 1007 / s00445-018-1225- 1.

Heap, M. J., Y. Lavallee, A. Laumann, K.-. U. Hess, P. G. Meredith, and D. B. Dingwell (2012). "How tough is tuff in the event of fire?" Geology 40.4, pp. 311-314. Dor: $10.1130 /$ g32940.1.

Heap, M. J., Y. Lavallée, L. Petrakova, P. Baud, T. Reuschlé, N. R. Varley, and D. B. Dingwell (2014a). "Microstructural controls on the physical and mechanical properties of edifice-forming andesites at Volcán de Colima, Mexico". Journal of Geophysical Research: Solid Earth 119.4, pp. 2925-2963. DoI: 10 . 1002 / 2013 jb0 10521. 
Heap, M., Y. Lavallée, A. Laumann, K.-U. Hess, P. Meredith, D. Dingwell, S. Huismann, and F. Weise (2013). "The influence of thermal-stressing (up to $1000^{\circ} \mathrm{C}$ ) on the physical, mechanical, and chemical properties of siliceous-aggregate, high-strength concrete". Construction and Building Materials 42, pp. 248-265. Dor: $10.1016 / \mathrm{j}$. conbuildmat . 2013. 01.020.

Heiken, G. (2006). Tuffs: their properties, uses, hydrology, and resources. Vol. 408. Geological Society of America.

Hoek, E. and Z. Bieniawski (1965). "Brittle fracture propagation in rock under compression". International Journal of Fracture Mechanics 1.3. Dor: 10.1007/ bf00186851.

Jackson, M. D., F. Marra, R. L. Hay, C. Cawood, and E. M. Winkler (2005). "The judicious selection and preservation of tuff and travertine building stone in ancient Rome". Archaeometry 47.3, pp. 485-510. DoI: $10.1111 / \mathrm{j} .1475-4754.2005 .00215 . x$.

Labuz, J. and J. Bridell (1993). "Reducing frictional constraint in compression testing through lubrication". International Journal of Rock Mechanics and Mining Sciences \& Geomechanics Abstracts 30.4, pp. 451-455. DoI: 10 . 1016/0148-9062 ( 93 ) 91726-y.

Lockner, D. (1993). "The role of acoustic emission in the study of rock fracture". International Journal of Rock Mechanics and Mining Sciences E Geomechanics Abstracts 30.7, pp. 883-899. DoI: 10 . $1016 / 0148$ 9062 ( 93 ) $90041-b$.

Marmoni, G., S. Martino, M. Heap, and T. Reuschlé (2017a). "Gravitational slope-deformation of a resurgent caldera: New insights from the mechanical behaviour of Mt. Nuovo tuffs (Ischia Island, Italy)". Journal of Volcanology and Geothermal Research 345, pp. 1-20. Dor: $10.1016 /$ j . jvolgeores . 2017.07 . 019.

- (2017b). "Multiphysics Laboratory Tests for Modelling Gravity-driven Instabilities at Slope Scale". Procedia Engineering 191, pp. 142-149. DoI: 10.1016/ j.proeng.2017.05.165.

Murad, E. (1996). "The Thermal Behaviour of an FeRich Illite". Clay Minerals 31.1, pp. 45-52. DoI: 10 . 1180/claymin. 1996.031.1.04.

Nabelek, P. I., A. G. Whittington, and A. M. Hofmeister (2010). "Strain heating as a mechanism for partial melting and ultrahigh temperature metamorphism in convergent orogens: Implications of temperaturedependent thermal diffusivity and rheology". Journal of Geophysical Research 115.B12. DoI: 10 . 1029 / 2010 jb007727.

Nijland, T. G., R. P. J. V. Hees, and L. Bolondi (2010). "Evaluation of three Italian tuffs (Neapolitan Yellow Tuff, Tufo Romano and Tufo Etrusco) as compatible replacement stone for Römer tuff in Dutch built cultural heritage". Geological Society, London, Special Publications 333.1, pp. 119-127. DoI: 10.1144 / sp333. 12.
Oguchi, C. T. and H. Yuasa (2010). "Simultaneous wetting/drying, freeze/thaw and salt crystallization experiments of three types of Oya tuff". Geological Society, London, Special Publications 333.1, pp. 59-72. Dor: 10.1144/sp333.6.

Orsi, G., G. Gallo, and A. Zanchi (1991). "Simpleshearing block resurgence in caldera depressions. A model from Pantelleria and Ischia". Journal of Volcanology and Geothermal Research 47.1-2, pp. 1-11. DoI: 10.1016/0377-0273(91)90097-j.

Pola, A., G. Crosta, N. Fusi, V. Barberini, and G. Norini (2012). "Influence of alteration on physical properties of volcanic rocks". Tectonophysics 566-567, pp. 67-86. Dor: 10.1016/ j . tecto.2012.07.017.

Ruedrich, J., D. Kirchner, and S. Siegesmund (2011). "Physical weathering of building stones induced by freeze-thaw action: a laboratory long-term study". Environmental Earth Sciences 63.7-8, pp. 1573-1586. DoI: 10 . 1007/s 12665-010-0826-6.

Russa, M. F. L., S. A. Ruffolo, M. Á. de Buergo, M. Ricca, C. M. Belfiore, A. Pezzino, and G. M. Crisci (2017). "The behaviour of consolidated Neapolitan yellow Tuff against salt weathering". Bulletin of Engineering Geology and the Environment 76.1, pp. 115-124. Dor: 10. 1007/s10064-016-0874-6.

Scholz, C. H. (1968). "Microfracturing and the inelastic deformation of rock in compression". Journal of Geophysical Research 73.4, pp. 1417-1432. DoI: 10.1029/ jb073i004p01417.

Seta, M. D., E. Marotta, G. Orsi, S. de Vita, F. Sansivero, and P. Fredi (2012). "Slope instability induced by volcano-tectonics as an additional source of hazard in active volcanic areas: the case of Ischia island (Italy)". Bulletin of Volcanology 74.1, pp. 79-106. Dor: 10. 1007/s00445-011-0501-0.

Siedel, H. (2010). "Historic Building Stones and Flooding: Changes of Physical Properties due to Water Saturation". Journal of Performance of Constructed Facilities 24.5, pp. 452-461. Dor: 10.1061/ (asce) cf. 1943-5509.0000066.

Tibaldi, A. and L. Vezzoli (1998). "The space problem of caldera resurgence: an example from Ischia Island, Italy". Geologische Rundschau 87.1, pp. 53-66. DoI: 10.1007/s005310050189.

Tomlinson, E. L., P. G. Albert, S. Wulf, R. J. Brown, V. C. Smith, J. Keller, G. Orsi, A. J. Bourne, and M. A. Menzies (2014). "Age and geochemistry of tephra layers from Ischia, Italy: constraints from proximaldistal correlations with Lago Grande di Monticchio". Journal of Volcanology and Geothermal Research 287, pp. 22-39. Dor: 10.1016/ j . jvolgeores . 2014.09 . 006.

Török, A., M. Gálos, and K. Kocsanyi-Kopecsko (2004). "Experimental weathering of rhyolite tuff building stones and the effect of an organic polymer conserving agent". Stone Decay: Its Causes and Controls. London/ New York: Routledge. Chap. 7, pp. 109-127. 
Vacchiano, C. D., L. Incarnato, P. Scarfato, and D. Acierno (2008). "Conservation of tuff-stone with polymeric resins". Construction and Building Materials 22.5, pp. 855-865. Dor: 10.1016/ j . conbuildmat. 2006.12 .012$.

Wolters, F. and K. Emmerich (2007). "Thermal reactions of smectites-Relation of dehydroxylation temperature to octahedral structure". Thermochimica Acta 462.1-2, pp. 80-88. Dor: 10.1016/ j . tca. 2007. 06.002.

Worrell, E., L. Price, N. Martin, C. Hendriks, and L. O. Meida (2001). "Carbon Dioxide Emissions from the Global Cement Industry". Annual Review of Energy and the Environment 26.1, pp. 303-329. DOI: 10 . 1146 / annurev . energy.26.1.303.
Yavuz, A. B. (2012). "Durability assessment of the Alaçatı tuff (Izmir) in western Turkey". Environmental Earth Sciences 67.7, pp. 1909-1925. DoI: 10.1007/ s12665-012-1632-0.

Zedef, V., K. Kocak, A. Doyen, H. Ozsen, and B. Kekec (2007). "Effect of salt crystallization on stones of historical buildings and monuments, Konya, Central Turkey". Building and Environment 42.3, pp. 14531457. Dor: 10.1016/ j . buildenv. 2005.12.010.

Zhu, W., P. Baud, S. Vinciguerra, and T.-f. Wong (2011). "Micromechanics of brittle faulting and cataclastic flow in Alban Hills tuff". Journal of Geophysical Research 116.B6. DoI: 10.1029/2010 jb008046. 